\title{
Effects of changes in number, identity and abundance of habitat-forming species on assemblages of rocky seashores
}

\author{
E. Maggi*, I. Bertocci, S. Vaselli, L. Benedetti-Cecchi \\ Dipartimento di Biologia, University of Pisa, CoNISMa, via Derna 1, Pisa 56126, Italy
}

\begin{abstract}
Understanding the relationship between variation in biodiversity and the alteration of ecosystem processes and stability has become a central ecological issue during the last decade. A large number of experimental and theoretical studies have focused on the effects of changes in species richness and identity, while the role of variation in species abundance has received less attention in biodiversity experiments. By using an experimental design that effectively separates the effects of species richness and identity, while controlling for variation in species abundance, we examined the consequences of loss of 2 habitat-forming species (the canopy alga Cystoseira compressa and the mussel Mytilus galloprovincialis) in Mediterranean low-shore assemblages of algae and invertebrates. Results revealed significant effects associated with changes in number and identity of habitatforming species on other organisms. The magnitude and direction of these effects, however, changed as a function of the abundance of manipulated species. Our findings indicate how changes in biodiversity of even 2 species can result in complex effects, stressing the importance of investigating nonrandom loss of habitat-forming species and the need to consider density-dependent effects in biodiversity experiments, particularly when experiments are undertaken in systems like rocky shores, where density-dependent effects are pervasive.
\end{abstract}

KEY WORDS: Biodiversity · Habitat-forming species $\cdot$ Experimental design $\cdot$ Density-dependence Rocky shore $\cdot$ Canopy algae $\cdot$ Mussels

\section{INTRODUCTION}

Understanding the consequences of alteration in biodiversity for ecosystem processes and society's use of natural resources (Vitousek 1994, Costanza et al. 1997, Chapin et al. 1998), has become one of the main issues in ecology (Hooper et al. 2005). In the last 2 decades, a large number of studies have focused on the importance of changes in number and identity of species in terrestrial habitats (Hooper \& Vitousek 1997, Tilman 1997, Loreau \& Hector 2001), with the ultimate goal of discriminating between complementarity and sampling effect models (Huston 1997, Loreau et al. 2001). More recently, however, experiments conducted in the marine realm have contributed to this debate, as documented in the review by Stachowicz et al. (2007).
Most studies that stressed a negative effect of loss of diversity on ecosystem processes were conducted in mesocosms or through synthetically assembled experiments, based on the assumption of random loss of species (e.g. Aarssen 1997, Huston 1997, Emmerson et al. 2001, Schmid et al. 2002). A few studies have focused on the selective removal of key species in the field, to simulate non-random changes in patterns of distribution and abundance of organisms (Schläpfer \& Schmid 1999, Loreau 2000, Dìaz \& Cabido 2001, Dìaz et al. 2003). These studies have emphasized the importance of focusing on species that have a clear functional role on the basis of their contribution to ecosystem processes (Schwartz et al. 2000, Geider et al. 2001, Loreau et al. 2002, Smith \& Knapp 2003); from this point of view, habitat-forming species (or ecosystem engineers; Hawkins \& Harkin 1985, Jones et al. 1994) warrant particular attention. 
In the marine environment, seaweed canopies (Dayton 1975, Menge 1978, Eckman et al. 1989, Bertness et al. 1999, Jenkins et al. 1999, 2004), seagrass (Orth 1977 , Irlandi \& Peterson 1991), or mussel beds (Suchanek 1985, Witman 1987) may play an important role in structuring assemblages, by modifying the physical features of the habitat through their morphologies. Removal experiments have been historically used to show these effects, but mostly in terms of presence or absence of a single species (Dayton 1975, Santelices \& Ojeda 1984, Connolly 1994). Multiple habitat-forming species can, however, coexist in the same place. Lowshore portions of rocky coasts in the north-western Mediterranean, for example, are characterised by mixed stands of the canopy-forming brown alga Cystoseira compressa (Esper) Gerloff \& Nizamuddin and the mussel Mytilus galloprovincialis Lamarck (BenedettiCecchi et al. 1996a). Canopy-forming algae and mussels are known to modify levels of light, temperature, water movement and sedimentation (Reed \& Foster 1984, Duggins et al. 1990, McCook \& Chapman 1991, Seed \& Suchanek 1992, Seed 1996, Commito et al. 2005), influencing other members of assemblages either positively, by ameliorating physical conditions and by providing opportunities for colonization, or negatively, by monopolizing resources (mostly space) and thereby preventing colonization (e.g. Dayton 1975, Kanter 1978, Paine \& Suchanek 1983, Bertness et al. 1999, Benedetti-Cecchi et al. 2001, Bulleri et al. 2002). Deletion experiments have clarified the roles of individual mussels and canopy algae in influencing the distribution and abundance of other species in these assemblages (Rodríguez-Prieto \& Polo 1996, BenedettiCecchi et al. 1996a, 2001). How assemblages respond to simultaneous changes in the abundance or presence/ absence of these species remains unknown.

In the present paper, we examined the effects of changes in number and identity of habitat-forming species (hereafter HFSs) on assemblages of algae and invertebrates on rocky shores in the north-western Mediterranean, through the selective removal of $\mathrm{Cys}$ toseira compressa and Mytilus galloprovincialis. Although common, these species may undergo drastic fluctuations in abundance and distribution due to natural and anthropogenic processes (Seapy \& Littler 1982, Rodríguez-Prieto \& Polo 1996, Benedetti-Cecchi et al. 2001). In addition to the presence/absence of target species, we also manipulated their abundances in various combinations to control for density-dependent effects (Benedetti-Cecchi 2004, 2006). Because C. compressa and M. galloprovincialis can have both positive and negative effects on other members of assemblages, we expected strong interactive effects associated with changes in the number, identity and abundance of these HFSs.

\section{MATERIALS AND METHODS}

Study site. The present study was conducted between November 2003 and November 2005, along the rocky coast of Calafuria, $10 \mathrm{~km}$ south of Livorno, Italy $\left(43^{\circ} 30^{\prime} \mathrm{N}, 10^{\circ} 20^{\prime} \mathrm{E}\right)$. Assemblages occurring between 0 and $-0.3 \mathrm{~m}$ below mean low water level on this coast were characterised by mixed stands of the brown alga Cystoseira compressa (Esper) Gerloff \& Nizamuddin and the mussel Mytilus galloprovincialis Lamarck. Assemblages also included encrusting algae (the coralline Lithophyllum orbiculatum [Foslie] Foslie and the brown Nemoderma tingitanum Schousboe ex Bornet) and articulated corallines (Corallina elongata Ellis and Solander, Jania rubens [Linné] Lamouroux and Haliptilon virgatum [Zanardini] Garbary \& Johansen), filamentous (Ceramium spp., Polysiphonia spp. and Cladophora spp.), coarsely branched (Laurencia obtusa [Hudson] Lamouroux, Chondria boryana [De Notaris] De Toni and Gastroclonium clavatum [Roth] Ardissone) and thin tubular sheet-like algae (Padina pavonica [Linnaeus] Thivy, Dictyota dichotoma [Hudson] J. V. Lamouroux and Dictyopteris membranacea [Stackhouse] Batters). The most common grazers were the limpets Patella ulyssiponensis Gmelin and $P$. caerulea Linnè and the topshell Osilinus turbinatus Von Born. Sessile invertebrates included the barnacle Balanus glandula Darwin and the tube-forming gastropod Vermetus triqueter Bivona-Bernardi (Menconi et al. 1999, Benedetti-Cecchi 2001). Organisms were identified to species level if possible and to morphological groups otherwise.

Experimental design. At the beginning of the study, 33 plots of $30 \times 30 \mathrm{~cm}$, with a cover of Cystoseira compressa and Mytilus galloprovincialis of no less than $30 \%$, were chosen along a stretch of coast of $1 \mathrm{~km}$ and marked at their corners with epoxy-putty (Subcoat S, Veneziani). Given the small size of the organisms sampled and the small spatial scales at which most of the variability occurs in these assemblages (BenedettiCecchi 2001), the size of the quadrats was considered appropriate to obtain representative estimates of abundance (Andrew \& Mapstone 1987). The percentage cover of these and other sessile organisms was estimated using a plastic frame divided into 25 subquadrats of $6 \times 6 \mathrm{~cm}$, and giving a score from 0 to $4 \%$ for each species in each sub-quadrat. Final cover was obtained by summing the values over the 25 subquadrats (Dethier et al. 1993, Benedetti-Cecchi et al. 1996b). The abundance of mobile animals was quantified as the number of individuals per quadrat.

The percentage cover values of Cystoseira compressa and of Mytilus galloprovincialis were adjusted experimentally to $30 \%$ in 3 randomly selected plots, which were designed as controls (unmanipulated 
plots; UP). Ideally, plots in which the 2 co-dominant species each covered $50 \%$ of the substratum would have been desirable for the experiment. Unfortunately, C. compressa and M. galloprovincialis rarely attained such large coverage values when sampled simultaneously at the scale of our plots. In contrast, plots in which the 2 co-dominant species each covered 30 to $40 \%$ of the substratum were common, and these were selected for the experiment. The other treatments were obtained by reducing the total cover of HFSs to 50,40 and $30 \%$ through the selective removal of C. compressa $\left(\mathrm{P}_{\mathrm{C}}\right.$ p partial removal of $C$. compressa), M. galloprovincialis $\left(\mathrm{P}_{\mathrm{M}}\right.$ i partial removal of $M$. galloprovincialis) or both species $\left(\mathrm{P}_{\mathrm{CM} i}\right.$ partial removal of $C$. compressa and $M$. galloprovincialis, in equal proportions), resulting in 9 treatment combinations. Reducing the total cover of HFSs to $30 \%$ resulted in experimental conditions in which either C. compressa or M. galloprovincialis were totally eradicated (indicated as $\mathrm{T}_{\mathrm{C}}$ and $\mathrm{T}_{\mathrm{M}}$, respectively). Hence, these treatments included only 1 HFS. Finally, there was a treatment in which both $C$. compressa and M. galloprovincialis were completely removed, so the cover of HFSs was $0 \%\left(\mathrm{~T}_{\mathrm{CM}}\right)$ (Table 1).

Treatments were obtained by removing the bases and erect fronds of the brown alga and shells and byssal threads of the mussels with a hammer and chisel, a paint scraper and a knife. Care was taken not to damage the surrounding organisms or to alter the morphology of the substratum by creating cracks and crevices. Abundances of all organisms (as percentage cover or number) were sampled at 7 dates, roughly every 3 to $4 \mathrm{mo}$. This frequency was chosen to ensure the detection of possible changes on the structure of assemblages given the temporal pattern of variability in abundance of organisms (Menconi et al. 1999, Benedetti-Cecchi 2001).

Analysis of data. Experimental conditions were maintained by visiting the shore approximately every 2 wk. Despite our efforts, however, rough sea prevented the adjustment of treatments as frequently as needed, so that the percentage cover of both Cystoseira compressa and Mytilus galloprovincialis were, on average, $6 \%$ above nominal levels. Importantly, relative differences in abundance among treatments were maintained for the most part over the study period, as shown in Fig. 1. As a consequence, our analyses focused on the average response of the assemblage over the course of the study. For this purpose, we analyzed the data with population averaged-generalized estimating equations (PA-GEEs; Liang \& Zeger 1986, Hardin \& Hilbe 2002), using the function 'geeglm' in the 'geepack'

Table 1. Experimental design with treatment codes

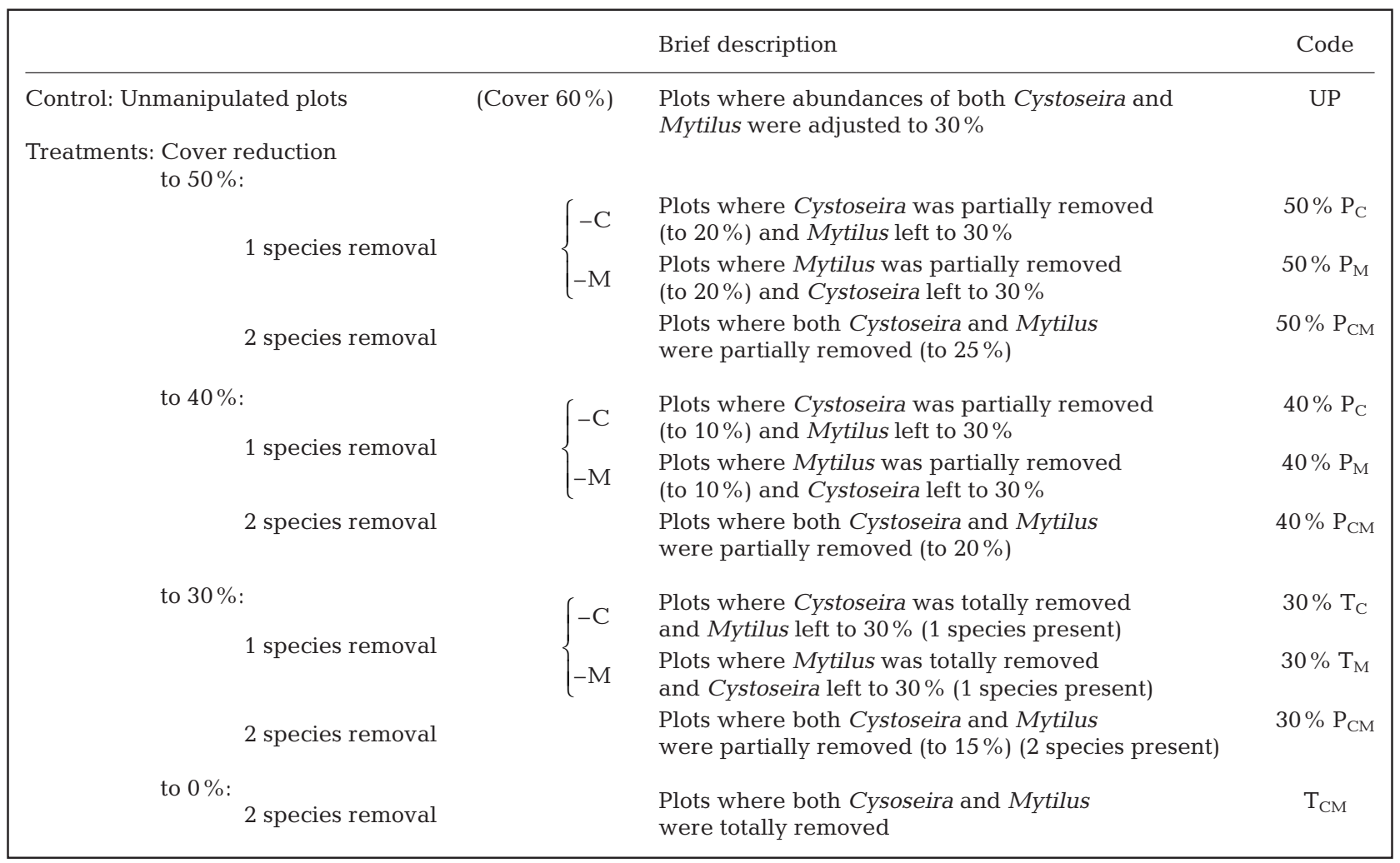




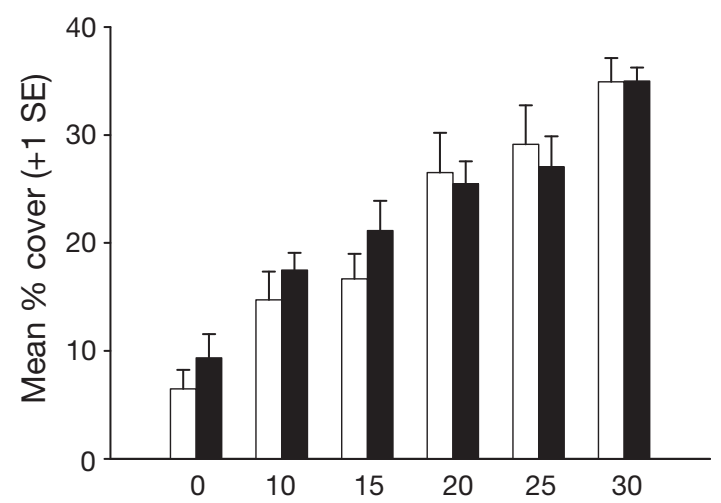

Percentage cover of habitat-forming species

Fig. 1. Cystoseira compressa (open bars), Mytilus galloprovincialis (filled bars). Mean percentage cover over the study period, for each level of experimental density (there were $\mathrm{n}=$ 12 replicate plots for $30 \%, \mathrm{n}=6$ for 20 and $0 \%$ and $\mathrm{n}=3$ replicates for all other experimental levels, averaged over 7 sampling dates over the course of the study; error bars are $\pm 1 \mathrm{SE}$ )

package of R 2.6.1 (R Development Core Team 2003). PA-GEEs allow analyses of correlated data, as in the case of experimental units repeatedly sampled through time, using the within-unit correlation structure to adjust the variance and standard errors of the estimated parameter. We used the first-order autoregressive model AR(1) to model temporal autocorrelation in response variables and fitted PA-GEE models assuming a Poisson distribution of the error terms and a log-link for the number of taxa, whereas a Gaussian distribution with the identity link was used for analyses of abundance data. Plots of standardized residuals versus fitted values and quantile-quantile plots were examined to check for strong deviations from the assumptions of the fitted models.

We examined several treatment contrasts, corresponding to specific hypotheses about the effects of changing the number, identity and cover of HFSs. First, control plots were compared with all the other treatments to examine a general effect due to the manipulation of HFSs (contrast UP vs. Treatments). We then assessed the effect of losing Cystoseira compressa and Mytilus galloprovincialis simultaneously, by comparing the $\mathrm{T}_{\mathrm{CM}}$ condition ( $0 \%$ cover) with all the other manipulated treatments (contrast Other treatments vs. $\mathrm{T}_{\mathrm{CM}}$ ). Effects due to changes in number of manipulated species were examined by comparing plots from which both species were removed with plots from which only 1 species was deleted, regardless of its identity (contrast $\mathrm{P}_{\mathrm{CM}}$ vs. $\mathrm{P}_{\mathrm{C}} / \mathrm{P}_{\mathrm{M}}$, where $\mathrm{P}_{\mathrm{C}} / \mathrm{P}_{\mathrm{M}}$ indicates the removal of either $C$. compressa or $M$. galloprovincialis). To examine identity effects, we contrasted plots from which only $C$. compressa was removed with plots from which only $M$. galloprovincialis was removed (contrast
$\mathrm{P}_{\mathrm{C}}$ vs. $\left.\mathrm{P}_{\mathrm{M}}\right)$. Both these contrasts were examined in interaction with changes in cover, to separate the effects of number and identity of manipulated species from those due to changes in their abundance. This first set of tests was limited to plots in which both HFSs were always present, i.e. at covers of 40 and $50 \%$. Further tests were done at the abundance of $30 \%$, and involved comparisons between plots that included both species $\left(\mathrm{P}_{\mathrm{CM}}\right)$ and those that had either C. compressa (because mussels were totally removed, $\mathrm{T}_{\mathrm{M}}$ ) or M. galloprovincialis (because C. compressa was totally removed, $\mathrm{T}_{\mathrm{C}}$ ) (contrast $\mathrm{P}_{\mathrm{CM}}$ vs. $\mathrm{T}_{\mathrm{C}} / \mathrm{T}_{\mathrm{M}}$, i.e. 2 vs. 1 species present), and between treatments differing in the identity of the species present (contrast $T_{C}$ vs. $T_{M}$ ).

While these analyses were based on the orthogonal partitioning of degrees of freedom resulting in independent tests, they only contrasted a limited range of abundances of manipulated species. Additional tests were therefore performed to examine the effect of reducing the cover of 1 species across a wide range of experimental abundances (i.e. reductions in percentage cover values of individual species of 0,10,20 and $30 \%$ ), while holding the cover of the other species at the nominal value of $30 \%$. We examined both linear and quadratic contrasts to test the hypothesis that reductions in cover of HFSs have non-linear effects on response variables, as predicted under the general model that species interactions are not linear (May 1973). These are non-orthogonal tests, and they may have inflated Type I error rates. Nevertheless, we decided to perform these tests at the conventional level of $\alpha=0.05$ due to the limited amount of replication.

\section{RESULTS}

PA-GEEs on percentage cover of the most abundant taxa identified significant effects associated with changes in number, identity and abundance of HFSs. The effects due to changes in number of manipulated HFSs were revealed by the significant Cover $\times \mathrm{P}_{\mathrm{CM}}$ vs. $\mathrm{P}_{\mathrm{C}} / \mathrm{P}_{\mathrm{M}}$ interaction for red filamentous algae, Laurencia spp. and thin tubular sheet-like algae (Table 2, Fig. 2). Red filamentous algae were more abundant in $\mathrm{P}_{\mathrm{CM}}$ plots compared to $\mathrm{P}_{\mathrm{C}} / \mathrm{P}_{\mathrm{M}}$ plots when the cover of HFSs was reduced from 60 to $50 \%$. In contrast, $\mathrm{P}_{\mathrm{C}} / \mathrm{P}_{\mathrm{M}}$ plots had more filamentous algae than $\mathrm{P}_{\mathrm{CM}}$ plots when the cover of HFSs was reduced to $40 \%$ (Fig. 2). This interaction reflected the positive effect that a reduction in cover of Cystoseira compressa to $10 \%$, but not to $20 \%$, had on filamentous algae, as also suggested by a quadratic trend with an estimated coefficient (hereafter E) of $17.82(\mathrm{SE}=9.97, \mathrm{p}<0.1$ ) associated with the reduction of the brown alga. On the contrary, there was a significant non-linear effect of removing mussels while 
Table 2. Analyses of data using population-averaged generalized estimating equations (PA-GEEs). E: estimated coefficient; SE: standard error; $^{*}: \mathrm{p}<0.05 i^{* *}: \mathrm{p}<0.01_{i}^{* *}: \mathrm{p}<0.001$. Number of data points for each treatment $=21$

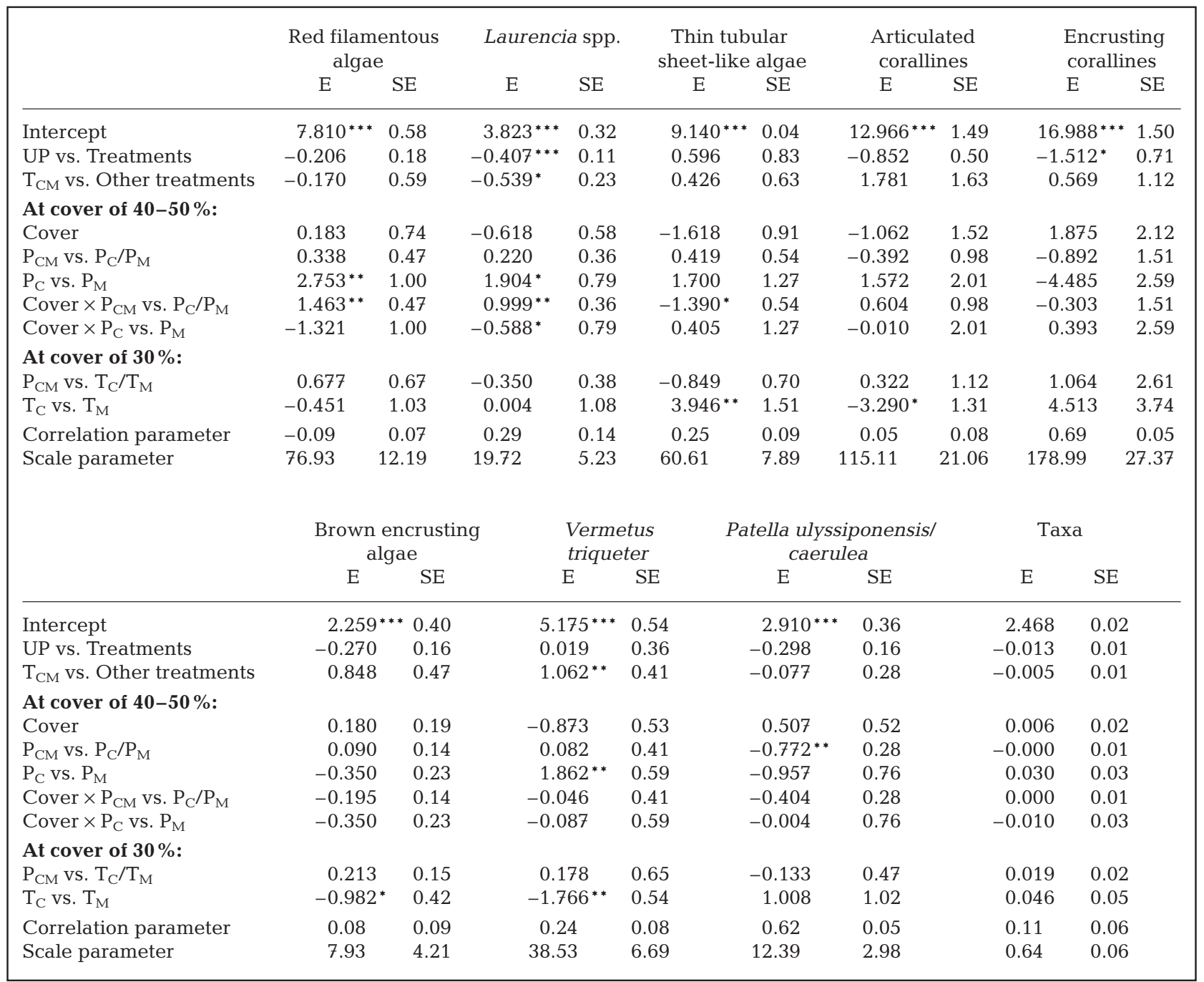

holding C. compressa constant (quadratic contrast: $\mathrm{E}=$ 9.392, $\mathrm{SE}=3.773, \mathrm{p}<0.05)$, due to a decline in red filamentous algae at intermediate levels of cover of the invertebrate. These identitied effects were also evidenced by the significant $\mathrm{P}_{\mathrm{C}}$ versus $\mathrm{P}_{\mathrm{M}}$ contrast (Table 2).

The same patterns just described for red filamentous algae were also observed for Laurencia spp. (Fig. 2, Table 2). In this case, however, there was a positive linear effect of removing Cystoseira compressa on the response variable (linear contrast: $\mathrm{E}=14.80, \mathrm{SE}=7.03$, $\mathrm{p}<0.05)$. In addition, Laurencia spp. were generally more abundant in manipulated compared to control plots, as indicated by the significant UP versus Treatments contrast (Table 2).

The significant Cover $\times \mathrm{P}_{\mathrm{CM}}$ versus $\mathrm{P}_{\mathrm{C}} / \mathrm{P}_{\mathrm{M}}$ interaction observed for thin tubular sheet-like algae reflected the negative effect of reducing to $10 \%$ either Cystoseira compressa or Mytilus galloprovincialis compared to values for plots in which the $2 \mathrm{HFSs}$ were manipulated simultaneously (patterns at $40 \%$ in Fig. 2), a trend that was reversed when the cover of either one or the other HFS was reduced to $20 \%$ (patterns at $50 \%$ in Fig. 2). In this case the removal of $C$. compressa resulted in a larger abundance of thin tubular sheet-like algae compared to that in plots where both HFSs species were manipulated or where only $M$. galloprovincialis was removed. This was evidence of an identity effect that was also present when the cover of HFSs was reduced to $30 \%$, as indicated by the significant $T_{C}$ versus $T_{M}$ contrast in Table 2.

A main significant effect of changes in number of manipulated HFSs $\left(\mathrm{P}_{\mathrm{CM}}\right.$ vs. $\left.\mathrm{P}_{\mathrm{C}} / \mathrm{P}_{\mathrm{M}}\right)$ was observed for Patella ulyssiponensis/caerula (Table 2), with an 


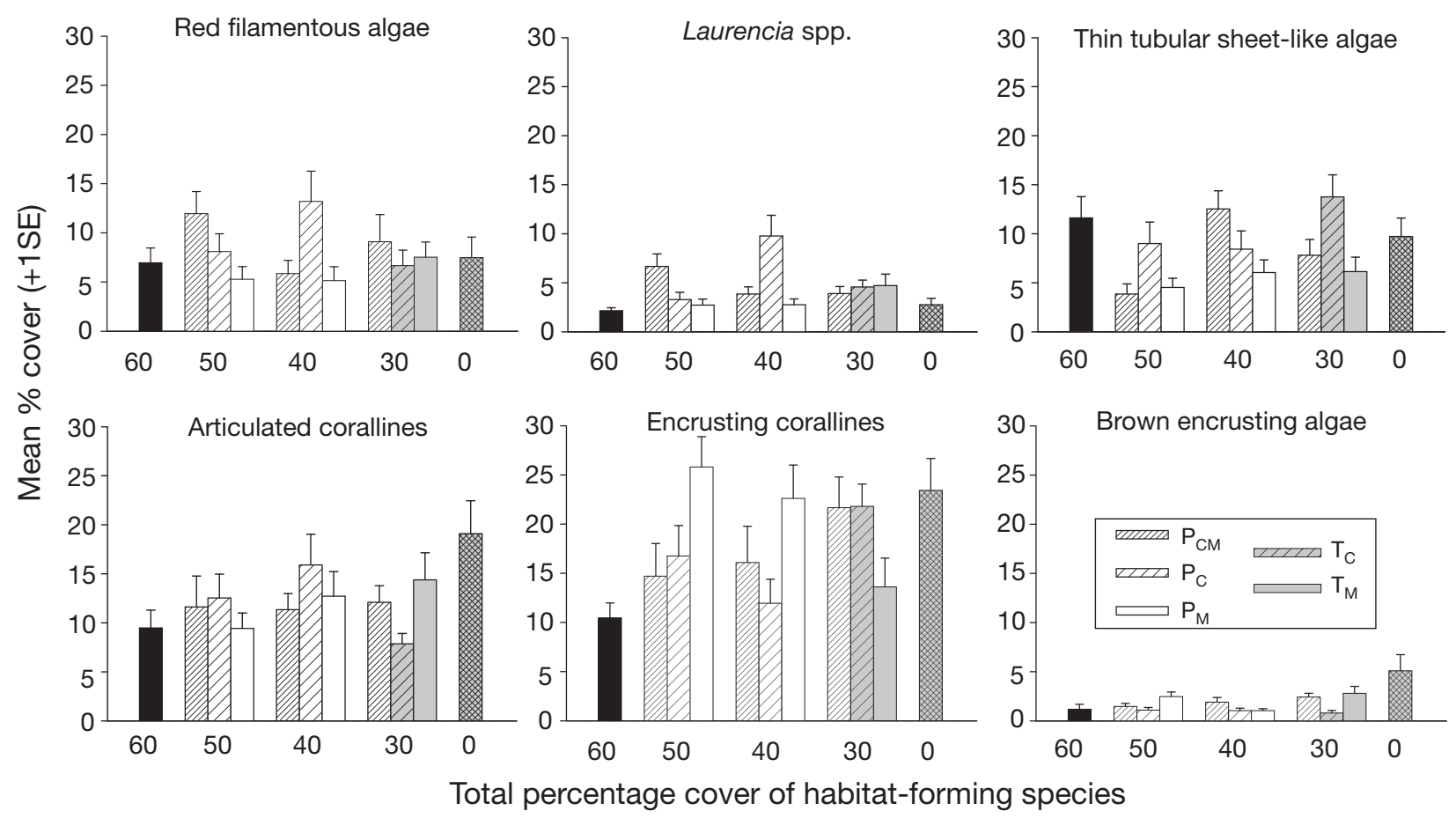

Fig. 2. Mean percentage cover of different macroalgae over the study period for each treatment $(\mathrm{n}=3$ replicate plots averaged over 7 sampling dates; error bars are $\pm 1 \mathrm{SE}$ ). Percentage values on the abscissa refer to the cover of the habitat-forming species Cystoseira compressa and Mytilus galloprovincialis. Treatments included in linear and quadratic contrasts were the unmanipulated plots (filled bars) and those coded with either subscript $\mathrm{C}$ or $\mathrm{M}$ (i.e. excluding $\mathrm{P}_{\mathrm{CM}}$ and the $0 \%$ treatment), depending on whether the contrasts examined the effect of removing C. compressa or M. galloprovincialis. $\mathrm{P}_{\mathrm{C}}$ : partial removal of C. compressa; $\mathrm{P}_{\mathrm{M}}$ : partial removal of M. galloprovincialis; $\mathrm{P}_{\mathrm{CM}}$ : partial removal of both C. compressa and M. galloprovincialis; $\mathrm{T}_{\mathrm{C}}$ : total removal of C. compressa; $\mathrm{T}_{\mathrm{M}}$ : total removal of M. galloprovincialis

increase in number of limpets especially when only mussels were reduced to 10 and $20 \%$ (Fig. 3).

The identity effect described for thin tubular sheetlike algae also occurred for articulated coralline algae, but in the opposite direction. In this case, there was a significant reduction in algal cover in plots cleared of Cystoseira compressa compared to plots where mussels were totally removed (Fig. 2 and $T_{C}$ vs. $\mathrm{T}_{\mathrm{M}}$ contrast in Table 2). Similar negative effects due to the removal of C. compressa were observed on brown encrusting algae (Fig. 2) and the invertebrate Vermetus triqueter (Fig. 3). In both cases there was a significant $T_{C}$ versus $T_{M}$ contrast (Table 2). The importance of an identity effect was also indicated for the invertebrate by the significant $\mathrm{P}_{\mathrm{C}}$ versus $\mathrm{P}_{\mathrm{M}}$ contrast (Table 2), i.e. when the cover of HFSs was reduced to $40-50 \%$ (Fig. 3). In this case, however, it was the removal of Mytilus galloprovincialis that depressed the cover of $V$. triqueter, rather than the removal of $C$. compressa as observed for the $\mathrm{T}_{\mathrm{C}}$ versus $\mathrm{T}_{\mathrm{M}}$ contrast. When examined across the full range of experimental densities, the effects of mussels was strongly non-linear, with the largest effect observed at the intermediate cover of $40 \%$ (quadratic contrast: $\mathrm{E}=15.167, \mathrm{SE}=4.964, \mathrm{p}<0.01)$.
Encrusting coralline algae were more abundant in manipulated than in control plots (UP vs. Treatments contrast; Table 2); in particular, there was a positive linear effect of removing Cystoseira compressa on encrusting coralline algae (linear contrast: $\mathrm{E}=30.0$, $\mathrm{SE}=15.1, \mathrm{p}<0.05$ ) (Fig. 2).

Finally, there was a slight, but significant non-linear positive effect of removing Cystoseira compressa on mean number of taxa, with larger values of the response variable at 40 and $50 \%$ cover of the brown alga (quadratic contrast: $\mathrm{E}=-0.47, \mathrm{SE}=0.22, \mathrm{p}<0.05$ ) (Fig. 3).

\section{DISCUSSION}

The present study pointed out how the simultaneous loss of 2 HFSs can result in complex interactive effects on associated assemblages and emphasized the importance of examining non-random loss of species and the need to control for density-dependent effects in biodiversity experiments.

Past studies conducted in terrestrial and aquatic systems highlighted variable effects of biodiversity on the biomass, productivity and structure of assemblages. 


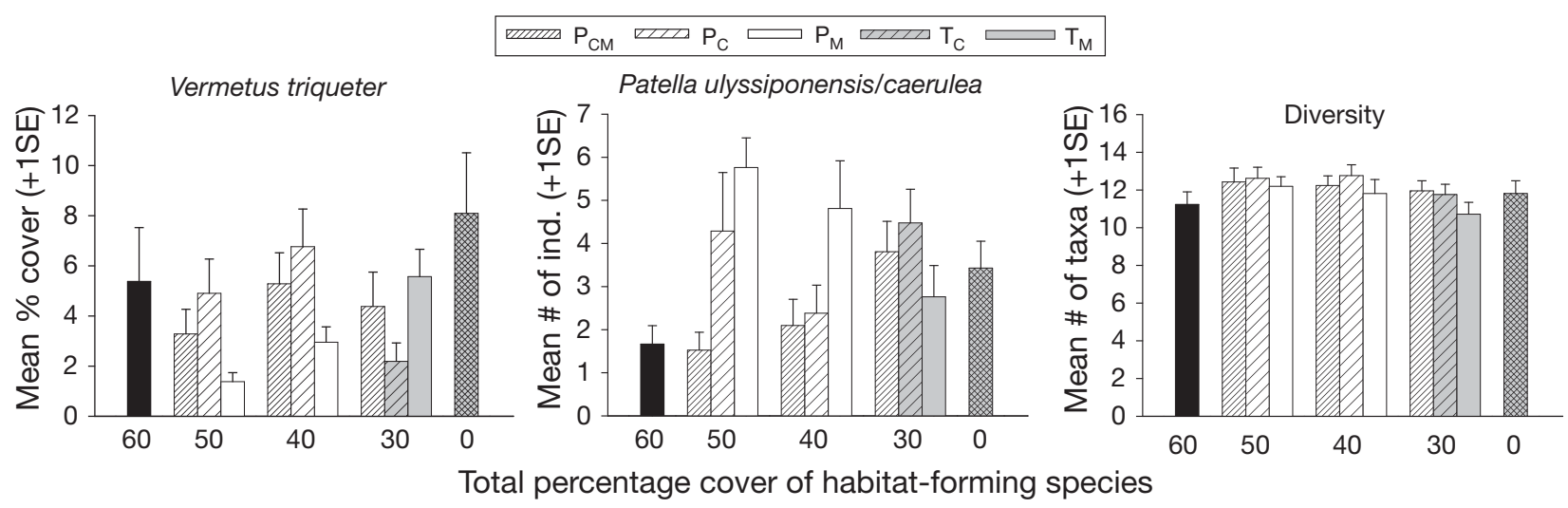

Fig. 3. Mean percentage cover of the tube-forming gastropod Vermetus triqueter, mean number of limpets Patella ulyssiponensis/caerulea and mean diversity over the study period for each treatment ( $\mathrm{n}=3$ replicate plots averaged over 7 sampling dates; error bars are $\pm 1 \mathrm{SE}$ ). Percentage values on the abscissa refer to the cover of the habitat-forming species Cystoseira compressa and Mytilus galloprovincialis. Treatments included in linear and quadratic contrasts were the unmanipulated plots (filled bars) and those coded with either subscript $\mathrm{C}$ or $\mathrm{M}$ (i.e. excluding $\mathrm{P}_{\mathrm{CM}}$ and the $0 \%$ treatment), depending on whether the contrasts examined the effect of removing C. compressa or $M$. galloprovincialis. $\mathrm{P}_{\mathrm{C}}$ : partial removal of C. compressa; $\mathrm{P}_{\mathrm{M}}$ : partial removal of M. galloprovincialis; $\mathrm{P}_{\mathrm{CM}}$ : partial removal of both C. compressa and M. galloprovincialis; $\mathrm{T}_{\mathrm{C}}$ : total removal of C. compressa; $\mathrm{T}_{\mathrm{M}}$ : total removal of M. galloprovincialis

Most terrestrial studies supported the conclusion that the net effect of diversity on biomass resulted from both species-specific selection effects and complementarity (Hooper et al. 2005, Cardinale et al. 2006). Recent studies on aquatic biodiversity, however, have documented strong responses to changes in species composition among experimental treatments, emphasizing the importance of identity effects (e.g. Bruno et al. 2005, O'Connor \& Crowe 2005, Moore \& Fairweather 2006, Vaughn et al. 2007). Our results have shown how the effect of changing the identity and number of HFSs may vary as a function of the abundance of manipulated species. Abundance, identity and richness effects could be disentangled in the present study because we explicitly manipulated the cover of HFSs as a factor in the experiment.

For several of the response variables analysed, both identity and richness effects (limited to 2 HFSs in the present study) occurred in interaction with the cover of manipulated species. In general, the effect that the removal of a particular HFS had on other organisms changed in magnitude and direction as a function of the relative abundance of the manipulated species. For example, a slight decrease in the cover of HFSs (from 60 to $50 \%$ ) led to an increase in abundance of some algae (red filamentous algae and the coarsely branched Laurencia spp.) and a decrease in others (thin tubular sheet-like algae), but only when Cystoseira compressa and Mytilus galloprovincialis were both removed (treatment $\mathrm{P}_{\mathrm{CM}}$ ). At lower abundances of manipulated species $(40 \%)$, however, positive effects were observed only in treatments where C. compressa was removed and mussels were left intact. Identity effects still occurred when the cover of HFSs was reduced to $30 \%$. In this case, however, the complete removal of mussels was important, causing a reduction in cover of thin tubular sheet-like algae and enhancing the abundance of articulated coralline and brown encrusting algae. Identity effects also influenced the percentage cover of the encrusting invertebrate Vermetus triqueter and occurred at different abundances of $\operatorname{HFSs}(50,40$ and $30 \%)$.

Our results are in agreement with the outcomes of past studies that have documented both positive and negative responses of species to the removal of either canopy-algae or mussels (Dayton 1975, Kanter 1978, Paine \& Suchanek 1983, Bertness et al. 1999, Benedetti-Cecchi et al. 2001, Bulleri et al. 2002, Chapman et al. 2005). By manipulating Cystoseira compressa and Mytilus galloprovincialis simultaneously, however, we generated complex responses in associated assemblages that likely involved a wide range of direct and indirect effects (Wootton 1994, and references therein). Importantly, in our study, these effects were largely a function of the abundance at which species interacted, highlighting the potential problems that might result from employing substitutive or additive designs that do not control for density-dependent effects in biodiversity experiments (Benedetti-Cecchi 2004, 2006).

The notion that identity effects are important determinants of ecological processes, as emphasized in biodiversity-ecosystem functioning studies, reiterates what ecologists and biologists have discovered in several decades of research on species life histories. Consideration of the morphology and life history of certain species is, therefore, important in order to understand how the removal of these species may have affected 
other organisms. Mussel shells, for example, offer a suitable substratum for the colonization of many algae and invertebrates, but they can also prevent colonization of primary space by forming closed beds. Similarly, Cystoseira compressa had short fronds, so the understory environment was limited compared to that provided by other congeneric species with larger fronds (Benedetti-Cecchi et al. 2001, Bulleri et al. 2002). Hence, negative effects due to pre-emption of the substratum may have outweighed the positive effects due to the provision of an understory environment. These effects were particularly evident for Laurencia spp. and encrusting coralline algae, the cover of which increased linearly with a decrease in abundance of C. compressa, as revealed by significant linear contrasts in the analyses.

While the effects of mussels in competitively excluding other invertebrates or macroalgae are well documented (Paine 1966, Dayton 1971, Menge 1976, Paine 1984, Enderlein \& Wahl 2004, Miyamoto \& Noda 2004), much less is known about how small-canopy algae like Cystoseira compressa interact with other species. In terrestrial habitats, the balance of facilitation and competition is known to vary with the life stages and physiologies of interacting species and with indirect interactions involving other organisms (Walker \& Vitousek 1991, Chapin et al. 1994, Miller 1994, Callaway et al. 1996). In the aquatic realm, switches from positive to negative effects have been observed along environmental gradients of stress (Bruno et al. 2003), and with different canopy- forming species, along vertical gradients (Hawkins 1983, Jenkins et al. 1999). In our analyses, switches in the direction of the effects of HFSs on other organisms were revealed clearly by the quadratic contrasts. These contrasts examined the effect of reducing the cover of one HFS across a wide range of experimental abundances, while holding the cover of another HFS at the nominal value of $30 \%$. Non-linear effects were common, with mussels maintaining high cover of filamentous algae and Vermetus sp. when unmanipulated (30\% cover) or when totally eradicated, but not when they were present at intermediate abundances. A similar relationship occurred between $C$. compressa and filamentous algae. Canopy cover was also non-linearly related to the mean number of taxa in quadrats, with the largest diversity observed under intermediate values of canopy abundance. These non-linear interactions indicated that a small change in cover was sufficient to trigger a shift from positive to negative (or negative to positive) effects of the HFSs on other organisms, highlighting the interplay between resource availability and facilitation in these assemblages (Bertness \& Leonard 1997, Bertness et al. 1999, Menge 2000, Bulleri et al. 2008).

Changes in cover or presence/absence of HFSs can potentially influence both primary producers and herbivores. In the investigated system, the most important grazers were limpets. These herbivores were rarely observed on mussel shells, whilst they were common in natural gaps within the canopy of Cystoseira compressa (authors' pers. obs.), suggesting a strong identity effect of HFSs on grazers. Our results, in contrast, highlighted a significant effect of the number of manipulated HFSs on the abundance of limpets, with treatments in which only one HFS was removed having larger densities of grazers compared to treatments in which both HFSs were manipulated. A possible explanation is that when present in uneven abundances (especially with the prevalence of the canopy alga), mussels and $C$. compressa would improve the quality of the habitat (in terms of food and/or in terms of substratum attachment).

Recently, some authors have pointed out the importance of considering the effects of biodiversity on different aspects of assemblage structure and ecosystem functioning (Hector \& Bagchi 2007). This is particularly applicable to multilayered assemblages of rocky shores. A number of experimental studies have revealed strong responses of mobile macrofauna, including amphipods, isopods and polychaetes, to the removal of canopy algae or mussels (Commito \& Dankers 2001, Thrush et al. 2001, Thiel \& Ullrich 2002, Goodsell \& Connell 2005, Schmidt \& Scheibling 2007). Examining the effects of HFSs on these assemblages could, therefore, provide different answers to those obtained by focusing on sessile macro-organisms, the customary approach in this type of study. Our results indicated only a slight effect of HFSs (due to the removal of Cystoseira compressa) on diversity, measured at a coarse level of taxonomic resolution as the total number of taxa; a different outcome might have emerged if we had focused on mobile macrofauna, which is an important component of the overall diversity of these assemblages.

Recent biodiversity experiments in marine environments have added important insights to general debate on the role of biodiversity in ecosystem functioning. Here, the relatively small size and fast growing rates of organisms inhabiting assemblages dominated by the mussel Mytilus galloprovincialis and the canopy alga Cystoseira compressa enabled us to conduct a complex removal experiment to examine the effects associated with changes in number, identity and abundance of HFSs. Our findings highlighted the importance of density-dependent processes in modulating the effects due to the changes in number and identity of HFSs. Because density-dependent processes are pervasive in nature (Barkai \& McQuaid 1988, Robinson \& Edgemon 1988, Drake 1991, Rand 2003, Griffin et al. 2008), it is desirable that future biodiversity experi- 
ments explicitly consider density effects with the appropriate designs (He et al. 2005, Benedetti-Cecchi 2004, O'Connor \& Crowe 2005) to foster progress in understanding of biodiversity-ecosystem functioning relationships.

Acknowledgements. We thank F. Bulleri for helpful comments on the manuscript, and L. Di Giacomo, F. Lemmi, M. Incera, M. Mazzi, C. Valleggi and F. Zoppi for assistance in the field. This study is part of a PhD dissertation by E.M. at the University of Pisa. This is publication number MPS-09031 of the MarBEF Network of Excellence.

\section{LITERATURE CITED}

Aarssen LW (1997) High productivity in grassland ecosystems: Effected by species diversity or productive species? Oikos 80:183-184

Andrew NL, Mapstone BD (1987) Sampling and the description of spatial pattern in marine ecology. Oceanogr Mar Biol Annu Rev 25:39-90

Barkai A, McQuaid CD (1988) Predator-prey role reversal in a marine benthic ecosystem. Science 242:62-64

Benedetti-Cecchi L (2001) Variability in abundance of algae and invertebrates at different spatial scales on rocky sea shores. Mar Ecol Prog Ser 215:79-92

Benedetti-Cecchi L (2004) Increasing accuracy of causal inference in experimental analyses of biodiversity. Funct Ecol 18:761-768

Benedetti-Cecchi L (2006) Understanding the consequences of changing biodiversity on rocky shores: How much have we learned from past experiments? J Exp Mar Biol Ecol 338:193-204

Benedetti-Cecchi L, Nuti S, Cinelli F (1996a) Analysis of spatial and temporal variability in interactions among algae, limpets and mussels, in low shore habitats on the west coast of Italy. Mar Ecol Prog Ser 144:87-96

Benedetti-Cecchi L, Airoldi L, Abbiati M, Cinelli F (1996b) Estimating the abundance of benthic invertebrates: a comparison of procedures and variability between observers. Mar Ecol Prog Ser 138:93-101

Benedetti-Cecchi L, Pannacciulli F, Bulleri F, Moschella PS, Airoldi L, Relini G, Cinelli F (2001) Predicting the consequences of anthropogenic disturbance: large-scale effects of loss of canopy algae on rocky shores. Mar Ecol Prog Ser 214:137-150

Bertness MD, Leonard GH (1997) The role of positive interactions in communities: lessons from intertidal habitats. Ecology 78:1976-1989

Bertness MD, Leonard GH, Levine JM, Schmidt PR, Ingraham AO (1999) Testing the relative contribution of positive and negative interactions in rocky intertidal communities. Ecology 80:2711-2726

Bruno JF, Stachowicz JJ, Bertness MD (2003) Inclusion of facilitation into ecological theory. Trends Ecol Evol 18: 119-125

Bruno JF, Boyer KE, Duffy JE, Lee SC, Kertesz JS (2005) Effects of macroalgal species identity and richness on primary production in benthic marine communities. Ecol Lett 8:1165-1174

Bulleri F, Benedetti-Cecchi L, Acunto S, Cinelli F, Hawkins SJ (2002) The influence of canopy algae on vertical patterns of distribution of low-shore assemblages on rocky coasts in the northwest Mediterranean. J Exp Mar Biol Ecol 267:89-106
Bulleri F, Bruno JF, Benedetti-Cecchi L (2008) Beyond competition: incorporating positive interactions between species to predict ecosystem invasibility. PLoS Biol 6(6): e162.doi:10.1371/journal.pbio.0060162

Callaway RM, DeLucia EH, Moore D, Nowak R, Schlesinger WH (1996) Competition and facilitation: contrasting effects of Artemisia tridentata on Pinus ponderosa and $P$. monophylla. Ecology 77:2130-2141

Cardinale BJ, Srivastava DS, Duffy JE, Wright JP, Downing AL, Sankaran M, Jouseau C (2006) Effects of biodiversity on the functioning of trophic groups and ecosystems. Nature 443:989-992

> Chapin FS III, Walzer LR, Fastie CL, Sharman LC (1994) Mechanisms of primary succession following deglaciation at Glacier Bay, Alaska. Ecol Monogr 64:149-175

> Chapin FS III, Sala OE, Burke IC, Grime JP and others (1998) Ecosystem consequences of changing biodiversity. Bioscience 48:45-52

Chapman MG, People J, Blockley D (2005) Intertidal assemblages associated with natural corallina turf and invasive mussel beds. Biodivers Conserv 14:1761-1776

Commito JA, Dankers N (2001) Dynamics of spatial and temporal complexity in European and North American softbottom mussel beds. In: Reise K (ed) Ecological comparison of sedimentary shores. Springer-Verlag, Heidelberg

Commito JA, Celano EA, Celico HJ, Como S, Johnson CP (2005) Mussels matter: postlarval dispersal dynamics altered by a spatially complex ecosystem engineer. J Exp Mar Biol Ecol 316:133-147

Connolly RM (1994) Removal of seagrass canopy: effects on small fish and their prey. J Exp Mar Biol Ecol 184:99-110

> Costanza R, D'Arge R, De Groot R, Farber S and others (1997) The value of the world's ecosystem services and natural capital. Nature 387:253-260

Dayton PK (1971) Competition, disturbance, and community organization: the provision and subsequent utilization of space in a rocky intertidal community. Ecol Monogr 41: 351-389

Dayton PK (1975) Experimental studies of algal canopy interactions in a sea otter-dominated kelp community at Amchitka Island, Alaska. Fish Bull 73:230-237

Dethier MN, Graham ES, Cohen S, Tear LM (1993) Visual versus random-point percent cover estimations: 'objective' is not always better. Mar Ecol Prog Ser 96:93-100

Dìaz S, Cabido M (2001) Vive la différence: plant functional diversity matters to ecosystem processes. Trends Ecol Evol 16:646-655

> Dìaz S, Symstad AJ, Chapin FS III, Wardle DA, Huenneke LF (2003) Functional diversity revealed by removal experiments. Trends Ecol Evol 18:140-146

Drake JA (1991) Community-assembly mechanics and the structure of an experimental species ensemble. Am Nat 137:1-26

Duggins DO, Eckman JE, Sewell AT (1990) Ecology of understory kelp environments. II. Effects of kelps on recruitment of benthic invertebrates. J Exp Mar Biol Ecol 143:27-45

Eckman JE, Duggins DO, Sewell AT (1989) Ecology of understory kelp environments. I. Effects of kelps on flow and particle transport near the bottom. J Exp Mar Biol Ecol 129:173-187

> Emmerson MC, Solan M, Emes C, Paterson DP, Raffaelli DG (2001) Consistent patterns and the idiosyncratic effects of biodiversity in marine ecosystems. Nature 411:73-77

> Enderlein P, Wahl M (2004) Dominance of blue mussels versus consumer-mediated enhancement of benthic diversity. J Sea Res 51:145-155

Geider RJ, Delucia EH, Falkowsky PG, Finzi AC, Grime JP, 
Grace J, Kana TM, La Roche L and others (2001) Primary productivity of planet earth: biological determinants and physical constraints in terrestrial and aquatic habitats. Glob Change Biol 7:849-882

Goodsell PJ, Connell SD (2005) Historical configuration of habitat influences the effects of disturbance on mobile invertebrates. Mar Ecol Prog Ser 299:79-87

Griffin JN, de la Haye KL, Hawkins SJ, Thompson RC, Jenkins SR (2008) Predator diversity and ecosystem functioning: density modifies the effects of resource partitioning. Ecology 89:298-305

Hardin JW, Hilbe JM (2002) Generalized estimating equations. Chapman \& Hall/CRC, Boca Raton, FL

> Hawkins SJ (1983) Interactions of Patella and macroalgae with settling Semibalanus balanoides (L.). J Exp Mar Biol Ecol 71:55-72

Hawkins SJ, Harkin E (1985) Preliminary canopy removal experiments in algal dominated communities low on the shore and in the shallow subtidal of the Isle of Man. Bot Mar 28:223-230

> He JS, Wolfe-Bellin KS, Schmid B, Bazzaz FA (2005) Density may alter diversity-productivity relationships in experimental plant communities. Basic Appl Ecol 6:505-517

Hector A, Bagchi R (2007) Biodiversity and ecosystem multifunctionality. Nature 448:188-191

Hooper DU, Vitousek PM (1997) The effects of plant composition and diversity on ecosystem processes. Science 277 : 1302-1305

Hooper DU, Chapin FS III, Ewell JJ, Hector A and others (2005) Effects of biodiversity on ecosystem functioning: a consensus of current knowledge. Ecol Monogr 75:3-35

Huston MA (1997) Hidden treatments in ecological experiments: re-evaluating the ecosystem function of biodiversity. Oecologia 110:449-460

Irlandi EA, Peterson CH (1991) Modification of animal habitat by large plants: mechanisms by which seagrasses influence clam growth. Oecologia 87:307-318

Jenkins SR, Hawkins SJ, Norton TA (1999) Direct and indirect effects of macroalgal canopy and limpet grazing in structuring a sheltered intertidal community. Mar Ecol Prog Ser 188:81-92

Jenkins SR, Norton TA, Hawkins SJ (2004) Long term effects of Ascophyllum nodosum canopy removal on mid shore community structure. J Mar Biol Assoc UK 84:327-329

Jones CG, Lawton JH, Shachak M (1994) Organisms as ecosystem engineers. Oikos 69:373-386

Kanter RG (1978) Mussel communities. In: Littler MM (ed) The annual and seasonal ecology of southern California rocky intertidal, subtidal and tidepool biotas. Southern California Baseline Study. Final report, Vol III. US Department of Interior, Bureau of Land Management, Washington, DC

> Liang KY, Zeger SL (1986) Longitudinal data analysis using generalized linear models. Biometrika 73:13-22

> Loreau M (2000) Biodiversity and ecosystem functioning: recent theoretical advances. Oikos 91:3-17

> Loreau M, Hector A (2001) Partitioning selection and complementarity in biodiversity experiments. Nature 412:72-76

Loreau M, Naeem S, Inchausti P, Bengtsson J and others (2001) Biodiversity and ecosystem functioning: current knowledge and future challenges. Science 294:804-808

Loreau M, Naeem S, Inchausti P (2002) Biodiversity and ecosystem functioning: synthesis and perspectives. Oxford University Press, Oxford

May RM (1973) Stability and complexity in model ecosystems. Princeton University Press, Princeton, NJ

McCook LJ, Chapman ARO (1991) Community succession following massive ice-scour on an exposed rocky shore: effects of Fucus canopy algae and of mussels during late succession. J Exp Mar Biol Ecol 154:137-169

> Menconi M, Benedetti-Cecchi L, Cinelli F (1999) Spatial and temporal variability in the distribution of algae and invertebrates on rocky shores in the northwest Mediterranean. J Exp Mar Biol Ecol 233:1-23

Menge BA (1976) Organization of the New England rocky intertidal community: role of predation, competition, and environmental heterogeneity. Ecol Monogr 46:355-393

> Menge BA (1978) Predation intensity in a rocky intertidal community. Oecologia 34:1-16

- Menge BA (2000) Testing the relative importance of positive and negative effects on community structure. Trends Ecol Evol 15:46-47

$>$ Miller TE (1994) Direct and indirect species interactions in an early old-field plant community. Am Nat 143:1007-1025

> Miyamoto Y, Noda T (2004) Effects of mussels on competitively inferior species: competitive exclusion to facilitation. Mar Ecol Prog Ser 276:293-298

> Moore TN, Fairweather PG (2006) Decay of multiple species of seagrass detritus is dominated by species identity, with an important influence of mixing litters. Oikos 114: $329-337$

O'Connor NE, Crowe TP (2005) Biodiversity loss and ecosystem functioning: distinguishing between number and identity of species. Ecology 86:1783-1796

Orth RJ (1977) The importance of sediment stability in seagrass. In: Coull BC (ed) Ecology of marine benthos. University of South Carolina Press, Columbia, SC, p 281-300

> Paine RT (1966) Food web complexity and species diversity. Am Nat 100:65-75

Paine RT (1984) Ecological determinism in the competition for space. Ecology 65:1339-1348

Paine RT, Suchanek TH (1983) Convergence of ecological processes between independently evolved competitive dominants: a tunicate-mussel comparison. Evolution 37: 821-831

R Development Core Team (2003) R: a language and environment for statistical computing. R Foundation for Statistical Computing, Vienna. Available at: www.R-project.org

Rand TA (2003) Herbivore-mediated apparent competition between two salt marsh forbs. Ecology 84:1517-1526

> Reed DC, Foster MS (1984) The effects of canopy shading on algal recruitment and growth in a giant kelp forest. Ecology 65:937-948

Robinson JV, Edgemon MA (1988) An experimental evaluation of the effect of invasion history on community structure. Ecology 69:1410-1417

Rodríguez-Prieto C, Polo L (1996) Effects of sewage pollution in the structure and dynamics of the community of Cystoseira mediterranea (Fucales, Phaeophyceae). Sci Mar 60: 253-263

> Santelices B, Ojeda FP (1984) Recruitment, growth and survival of Lessonia nigrescens (Phaeophyta) at various tidal levels in exposed habitats at central Chile. Mar Ecol Prog Ser 19:73-82

Schläpfer F, Schmid B (1999) Ecosystem effects of biodiversity: a classification of hypotheses and exploration of empirical results. Ecol Appl 9:893-912

Schmid B, Hector A, Huston MA, Inchausti P, Nijs I, Leadley PW, Tilman D (2002) The design and analysis of biodiversity experiments. In: Loreau M, Naeem S, Inchausti P (eds) Biodiversity and ecosystem functioning: synthesis and perspectives. Oxford University Press, Oxford, p 61-75

> Schmidt AL, Scheibling RE (2007) Effects of native and invasive macroalgal canopies on composition and abundance 
of mobile benthic macrofauna and turf-forming algae. J Exp Mar Biol Ecol 341:110-130

Schwartz MW, Brigham CA, Hoeksema JD, Lyons KG, Mills $\mathrm{MH}$, van Mantgem PJ (2000) Linking biodiversity to ecosystem function: implication for conservation biology. Oecologia 122:297-305

Seapy RR, Littler MM (1982) Population and species diversity fluctuations in a rocky intertidal community relative to severe aerial exposure and sediment burial. Mar Biol 71:87-96

Seed R (1996) Patterns of biodiversity in the macro-invertebrate fauna associated with mussel patches on rocky shores. J Mar Biol Assoc UK 76:203-210

Seed R, Suchanek TH (1992) Population and community ecology of Mytilus. In: Gosling EG (ed) The mussel Mytilus: ecology, physiology, genetics and culture. Elsevier, New York, p 87-169

Smith MD, Knapp AK (2003) Dominant species maintain ecosystem function with non-random species loss. Ecol Lett 6:509-517

Stachowicz JJ, Bruno JF, Duffy JE (2007) Understanding the effects of marine biodiversity on communities and ecosystems. Annu Rev Ecol Evol Syst 38:739-766

Suchanek TH (1985) Mussels and their role in structuring rocky shore communities. In: Moore PG, Seed R (eds) The ecology of rocky coasts. Hodder and Stoughton, London,

Editorial responsibility: Roger Hughes,

Bangor, UK p 70-96

Thiel M, Ullrich N (2002) Hard rock versus soft bottom: the fauna associated with intertidal mussel beds on hard bottoms along the coast of Chile, and considerations on the functional role of mussel beds. Helgol Mar Res 56:21-30

> Thrush SF, Hewitt JE, Funnell GA, Cummings VJ and others (2001) Fishing disturbance and marine biodiversity: the role of habitat structure in simple soft-sediment systems. Mar Ecol Prog Ser 223:277-286

Tilman D (1997) Distinguishing between the effects of species diversity and species composition. Oikos 80:185

Vaughn CC, Spooner DE, Galbraith HS (2007) Contextdependent species identity effects within a functional group of filter-feeding bivalves. Ecology 88:1654-1662

Vitousek PM (1994) Beyond global warming: ecology and global change. Ecology 75:1861-1876

Walker LR, Vitousek PM (1991) An invader alters germination and growth of a native dominant tree in Hawai'i. Ecology 72:1449-1455

Witman JD (1987) Subtidal coexistence: storms, grazing, mutualism, and the zonation of kelps and mussels. Ecol Monogr 57:167-187

Wootton JT (1994) The nature and consequences of indirect effects in ecological communities. Annu Rev Ecol Syst 25: 443-466

Submitted: July 14, 2008; Accepted: January 27, 2009

Proofs received from author(s): April 1, 2009 